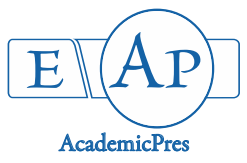

Wicaksono A and Teixeira da Silva JA (2020)

Notulae Scientia Biologicae 12(3):769-772

DOI: $10.15835 / \mathrm{nsb} 12310778$

Note

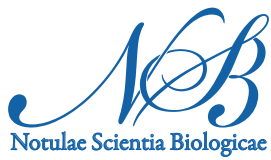

\title{
Is COVID-19 impacting plant science, and is plant science impacting COVID-19?
}

\author{
Adhityo WICAKSONO ${ }^{1 *}$, Jaime A. TEIXEIRA da SILVA ${ }^{2 *}$ \\ 'Division of Biotechnology, Generasi Biologi Indonesia (Genbinesia) Foundation, Jl. Swadaya Barat no. 4, Gresik Regency 61171, \\ Indonesia; adhitwicaksono@genbinesia.or.id (*corresponding author); \\ ${ }^{2}$ Independent researcher, P.O. Box 7, Miki-cho post office, Ikenobe 3011-2, Kagawa-ken, 761-0799, \\ Japan; jaimetex@yahoo.com ("correspondingauthor)
}

\begin{abstract}
COVID-19 changed 2020 massively after becoming a worldwide pandemic. Many countries affected by the disease witnessed disruptions in the agricultural, farming, industry, production and distribution sectors, causing a loss of crops due to reduced consumer demand. Sales of cut flowers, potted plants and seasonal crops that are sensitive to specific seasons or dates were affected, as were fertilizer and food security. Academics, including plant scientists, with limited work or research conditions during the pandemic, alleviated their work through alternative approaches, e.g., in silico research, or made more time to writing research papers, while student education has largely been placed on hold or held online by lecturers. Most COVID-19 research has focused primarily on medical and social aspects while some plant science-related research has been conducted on the use of traditional medicinal plants as possible alleviating agents, but not cures, to COVID-19 patients. The integrity of science and publishing, including research related to plants, is being tested as cases of superficial research, lax or superficial peer review, and misinformation abound. COVID-19 has thus had limited impact on plant science, and vice versa, thus far, even though it is likely that most plant scientists were affected.
\end{abstract}

Keywords: food security; herbal and medicinal plants; pandemic; plant-based medicine and vaccines; plant research; SARS-CoV-2; viruses

\section{Introduction}

In 2020, the world was radically transformed by the coronavirus disease (COVID-19) pandemic caused by the severe acute respiratory syndrome coronavirus type 2 (SARS-CoV-2) virus. Data from John Hopkins University states that, on July 16, 2020, COVID-19 had already infected 13,405,694 people and caused 580,552 mortalities around the world ${ }^{1}$. Countries have responded differently, including partial or total lockdowns, restricted travel, or physical social distancing, halting an estimated $81 \%$ of the global workforce 2 . In some countries, agriculture, farming, food, industrial, production and distribution sectors have come to a

\footnotetext{
${ }^{1}$ https://coronavirus.jhu.edu/map.html (last accessed: July 16, 2020).

${ }^{2}$ https://www.ilo.org/wcmsp5/groups/public/---dgreports/--_dcomm/documents/briefingnote/wcms_740877.pdf(last accessed: July 16, 2020).
} 
grinding halt, and commodity prices and profits have been slashed (Schmidhuber et al., 2020) ${ }^{3}$ as the workforce was paused or faced employment termination due to companies' financial woes, causing food and labor shortages (Nature Plants Editorial, 2020). Industrial agriculture, in response to this vulnerability, led to a waste of resources (Altieri and Nicholls, 2020). A slump in the prices of sulfuric acid may affect fertilizer markers ${ }^{4}$. Considering that $\sim 27 \%$ of the global working population works in agriculture 5 , COVID-19 will impact not only the agriculture sector, but society as a whole because supply chains are disrupted ${ }^{6}$. Food security may also be at risk ${ }^{7}$. Cut flowers, fresh produce and potted plants, many of which are seasonal, grown for specific dates and occasions, and which serve the ornamental, tourism, restaurant and many other axillary business sectors, were affected as fresh produce needed to be discarded due to spoilage and lack of demand ${ }^{8}$.

Education, including at universities, research institutions, and schools closed down (Viner et al., 2020)', and the internet became a virtual tool of communication and teaching, with online classes held for students, video-conference moderation by teachers at schools and lecturers or professors at universities, and online-based written assignments and exams (Almarzooq et al., 2020). In the fields of education and research, COVID-19 is likely having a similar impact on plant scientists as on other academics around the world although there is no direct study that has specifically assessed the impact on plant scientists.

Without access to universities, research institutions, or agricultural testing fields in COVID-19 red zones, many researchers in plant science have restricted access to research material and data. Even if granted access to the workplace, stringent regulations may negatively impact the workload, working environment and working period, forcing some to spend their time at home writing papers to avoid psychosocial problems (Bouziri et al., 2020). Some online resources and classes for education in plant science were provided by some institutions during the pandemic ${ }^{10}$. The use of bioinformatics databases and in silico approaches to research, such as in silico PCR, or modelling (e.g., molecular docking analysis), can be conducted remotely, allowing some productivity to continue.

Research has focused primarily on medical and social aspects of SARS-CoV-2 or COVID-19, but little on plant science, which has also been impacted, directly or indirectly. The most common is research on plant secondary metabolites or ethnomedicinal plants as possible treatments of COVID-19, e.g., Ul Qamar et al. (2020). Wu et al. (2020) provided a list of about a dozen traditional Chinese herbal and plant-based medicines that have alleviated the progression of COVID-19 while Vellingiri et al. (2020) postulated that Indian medicinal plants, which have shown promising antiviral properties against other viruses, may also show promise against COVID-19. However, using only molecular docking studies or reliance on antiviral properties reported against other coronaviruses (e.g., SARS-CoV or Middle East respiratory syndrome coronavirus), most of the studies listed by Wu et al. (2020) remain theoretical, and those by Vellingiri et al. (2020) are hypothetical, so their efficacy against COVID-19 remains speculative until clinical human trials can be completed.

Some good plant-based research may have practical value to global health. In the field of plant biotechnology, plants can be used for molecular farming, allowing plants to be engineered to produce antigens for vaccines or diagnostic reagents (Capell et al., 2020), i.e., plant-based vaccines against COVID-19 (RosalesMendoza et al., 2020). Some studies used in silico testing and molecular docking software to assess the efficiency of plant secondary metabolites and other chemical compounds against SARS-CoV-2 proteins (Mpiana et al.,

\footnotetext{
${ }^{3}$ https://www.bcg.com/ja-jp/publications/2020/agricultural-industry-to-bounce-back-post-covid-19.aspx (last accessed: July 16, 2020).

${ }^{4}$ https://www.bcg.com/ja-jp/publications/2020/agricultural-industry-to-bounce-back-post-covid-19.aspx (last accessed: July 16, 2020).

${ }^{5}$ https://ihsmarkit.com/research-analysis/report-covid19-effects-on-the-fertilizer-industry.html (last accessed: July 16, 2020).

${ }^{6}$ http://www.oecd.org/coronavirus/policy-responses/food-supply-chains-and-covid-19-impacts-and-policy-lessons-71b57aea/ (last accessed: July 16, 2020).

${ }^{7}$ https://www.ilo.org/wcmsp5/groups/public/---ed_dialogue/---sector/documents/briefingnote/wcms_742023.pdf (last accessed: July 16, 2020).

${ }^{8}$ https://www.floraldaily.com/article/9202961/covid-19-updates-from-around-the-world/ (last accessed: July 16, 2020).

${ }^{9}$ https://en.unesco.org/covid19/educationresponse (last accessed: July 16, 2020).

${ }^{10}$ https://sips.cals.cornell.edu/extension-outreach/covid-19-resources/; https://aec.ifas.ufl.edu/resources/ag-teachers/; https://community.plantae.org/article/5509561630179985405/online-plant-science-related-courses (last accessed: July 16, 2020).
} 
2020; Sampangi-Ramaiah et al., 2020). Plant-derived metabolites may in the future serve as effective disruptors of different components of SARS-CoV-2. For example, alkaloids might be used as an intracellular viral replication inhibitor DNA intercalating agent, phenolics bind with the membrane protein and spike protein, and essential oils (terpenes) can disrupt the viral lipid membrane due to their lipophilic nature (Jahan and Onay, 2020; Wink, 2020). Plant metabolites need to be clinically tested to support the findings of in silico modeling. The claims of ethnobotanical remedies serving as a cure or prophylaxis of COVID-19 are controversial, at best, since herbal medicine has both benefits and adverse effects (Vandebroek et al., 2020).

The integrity of the plant science literature is being put to the test by COVID-19. Excessive volumes, peer reviewer and editorial overload, resulting in editorial oversight (Chirico et al., 2020), and publishing too quickly invite the publication of erroneous research and the risk of bad science and predatory behavior (Teixeira da Silva, 2020) becoming part of the misinformation flow (Bell and Green 2020), issues that only postpublication peer review will be able to remedy over time.

\section{Conclusions}

Apart from direct impacts of COVID-19 on applied plant (agricultural crop) production, there is little evidence to suggest that plant science has been affected in any way as a field of study. The lives of plant scientist, as of other members of the public, has been disrupted, differently depending on the country, but there may be similarities in the lifestyle, social, psychological, educational and professional challenges that we have faced (Sofo and Sofo, 2020).

\section{Authors' Contributions}

Both authors wrote, read and approved the final manuscript.

\section{Acknowledgements}

This research received no specific grant from any funding agency in the public, commercial, or not-forprofit sectors.

\section{Conflict of Interests}

The authors declare that there are no conflicts of interest related to this article.

\section{References}

Almarzooq Z, Lopes M, Kochar A (2020). Virtual learning during the COVID-19 pandemic: a disruptive technology in graduate medical education. Journal of the American College of Cardiology 75(29):2635-2638. https://doi.org/10.1016/j.jacc.2020.04.015

Altieri MA, Nicholls CI (2020). Agroecology and the emergence of a post COVID-19 agriculture. Agriculture and Human Values 37:525-526. (in press) https://doi.org/10.1007/s10460-020-10043-7

Bell K, Green J (2020). Premature evaluation? Some cautionary thoughts on global pandemics and scholarly publishing. Critical Public Health 30(4):379-384. (in press) https://doi.org/10.1080/09581596.2020.1769406 
Bouziri H, Smith DRM, Descatha A, Dab W, Jean K (2020). Working from home in the time of covid-19: how to best preserve occupational health? Occupational and Environmental Medicine 77(7):509-510. https://doi.org/10.1136/oemed-2020-106599

Chirico F, Teixeira da Silva JA, Magnavita N (2020). "Questionable” peer review in the publishing pandemic during the time of Covid-19: Implications for policy makers and stakeholders. Croatian Medical Journal 61(3):300-301. https://doi.org/10.3325/cmj.2020.61.300

Jahan I, Onay A (2020). Potentials of plant-based substance to inhabit (sic) and probable cure for the COVID-19. Turkish Journal of Biology 44(3):228-241. https://doi.org/10.3906/biy-2005-114

Mpiana PT, Tshibangu DS, Kilembe JT, Gbolo BZ, Mwanangombo DT, Inkoto CL, ... Tshilanda DD (2020) Identification of potential inhibitors of SARS-CoV-2 main protease from Aloe vera compounds: a molecular docking study. Chemical Physics Letters 754:137751. https://doi.org/10.1016/j.cplett.2020.137751

Nature Plants Editorial (2020). Food in a time of COVID-19. Nature Plants 6:429. https://doi.org/10.1038/s41477020-0682-7

Rosales-Mendoza S, Márquez-Escobar VA, González-Ortega O, Nieto-Gómez R, Arévalo-Villalobos JI (2020). What does plant-based vaccine technology offer to the fight against COVID-19? Vaccines 8(2):E183. https://doi.org/10.3390/vaccines8020183

Sampangi-Ramaiah MH, Vishwakarma R, Shaanker RU (2020). Molecular docking analysis of selected natural products from plants for inhibition of SARS-CoV-2 main protease. Current Science 118(7):1087-1092. https://doi.org/10.18520/cs/v118/i7/1087-1092

Schmidhuber J, Pound J, Qiao B (2020). COVID-19: Channels of transmission to food and agriculture. Rome, FAO. https://doi.org/10.4060/ca8430en

Sofo A, Sofo A (2020). Converting home spaces into food gardens at the time of Covid-19 quarantine: all the benefits of plants in this difficult and unprecedented period. Human Ecology 48(2):131-139. https://doi.org/10.1007/s10745-020-00147-3

Teixeira da Silva JA (2020). An alert to COVID-19 literature in predatory publishing venues. The Journal of Academic Librarianship 46(5):102187. https://doi.org/10.1016/j.acalib.2020.102187

Ul Qamar MT, Alqahtani SM, Alamri MA, Chen LL (2020). Structural basis of SARS-CoV-2 3CL ${ }^{\text {pro }}$ and anti-COVID19 drug discovery from medicinal plants. Journal of Pharmaceutical Analysis 10(4):313-319 (in press) https://doi.org/10.1016/j.jpha.2020.03.009

Vandebroek I, Pieroni A, Stepp JR, Hanazaki N, Ladio A, Alves RRN, ... Quave CL (2020). Reshaping the future of ethnobiology research after the COVID-19 pandemic. Nature Plants 6:723-730. https://doi.org/10.1038/s41477-020-0691-6

Vellingiri B, Jayaramayya K, Iyer M, Narayanasamy A, Govindasamy V, Giridharan B, ... Subramaniam MD (2020). COVID-19: A promising cure for the global panic. Science of the Total Environment 725:138277. https://doi.org/10.1016/j.scitotenv.2020.138277

Viner RM, Russell SJ, Croker H (2020). School closure and management practices during coronavirus outbreaks including COVID-19: a rapid systematic review. Lancet Child Adolescent Health 4(5):397-404. https://doi.org/10.1016/S2352-4642(20)30095-X

Wink M (2020). Potential of DNA intercalating alkaloids and other plant secondary metabolites against SARS-CoV-2 causing COVID-19. Diversity 12(5):175. https://doi.org/10.3390/d12050175

Wu R, Wang L, Kuo HD, Shannar A, Peter R, Chou PJ, ... Kong AN (2020) An update on current therapeutic drugs treating COVID-19. Current Pharmacology Reports 6(3):56-70. https://doi.org/10.1007/s40495-020-00216-7
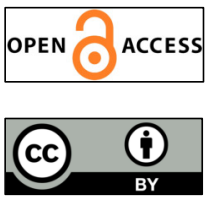

The journal offers free, immediate, and unrestricted access to peer-reviewed research and scholarly work. Users are allowed to read, download, copy, distribute, print, search, or link to the full texts of the articles, or use them for any other lawful purpose, without asking prior permission from the publisher or the author.

License - Articles published in Notulae Scientia Biologicae are Open-Access, distributed under the terms and conditions of the Creative Commons Attribution (CC BY 4.0) License.

(c) Articles by the authors; SHST, Cluj-Napoca, Romania. The journal allows the author(s) to hold the copyright/to retain publishing rights without restriction. 